\title{
FINANCIAL MANAGEMENT IN FOOD ENTERPRISES AND GLOBALIZATION OF ELECTRONIC BUSINESS IN SERBIA
}

\author{
Ivan Mičić ${ }^{1}$ Ibrahim Totić2 , Ahmet Halilagić3 \\ *Corresponding authorE-mail: divanlav@gmail.com
}

\begin{abstract}
A R T I C LE IN F O
A B S T R A C T

Review Article

Received: 28 August 2018

Accepted: 08 September 2018

doi:10.5937/ekoPolj1803259M

UDC 658.14/.17+663/664]:004. $738.5(497.11)$

Keywords:

accounting, economy, market orientation, consumer, Serbia

JEL: M5, M21

Use of finance in a certain form has been present and operational since the emergence of the world's first civilizations such as: Egypt, Greece, Babylon, Rome and others. At that time, however, the financial system was primarily based on archaic stores of value - gold or silver money. In its basic definition, finances were created with the concept of money and the development of its functions as a payment and transactional mechanisms. Where there is no money, there is no value. Money is the determinant, but also the function of finance. The development of finance as a science and its function relates to the emergence of the state, since it is the primary creater and backer of money. In this regard, public-state finances first began to be studied, followed by other finanical disciplines. Whereby the equilibrium arises from the payment of debt, collection of claims between states, enterprises and individuals.
\end{abstract}

(C) 2018 EA. All rights reserved.

\section{Introduction}

E-commerce is the purchase and sale of information, products and services through a computer network and support for various types of business transactions. It's about using online convenience and tools to enhance business processes to improve efficiency and productivty. E-commerce is a strategic business. It's not enough to simply introduce and apply the new technology. It is necessary to introduce organizational changes by creating a new business model. Due to strong global competition, international companies are under constant pressure to keep their customers, reduce costs, manage risk, and use technology as a source of competitive advantage. The model of global organization and strong competition requires a new concept of business, as evidenced

1 Ivan D. Mičić, Ph.D., MIT University of Skopje, Bul. Third Macedonian brigades 66a 1000 Skopje, Republic of Macedonia, Agent, Nis-Serbia, Phone:+381 629731158 , E-mail:divanlav@gmail.com

2 Ibrahim Totić, Associate professor, State University in Novi Pazar, Department of Legal and Economic Sciences, Vuka Karadžića bb, 36300 Novi Pazar; Phone. 003816387826 32; E-mail: ibrahimtotic@yahoo.com

3 Ahmet Halilagić, Ph.D. student, University of Belgrade, Faculty of Agriculture, Nemanjina Street no.6, 11080 Zemun, Republic of Serbia, Phone:+381 1126153 15, E-mail:ahmet.halilagic@hcg.rs

http://ea.bg.ac.rs 
by the increasing investment in specialized and client-oriented technology. The Internet is one such technology that enables the exploitation of the advantages of digital devices and connections, and in connection with digital information, with the goal of market entry and penetrating global markets.

The focus of this paper is the electronic business of global companies. The development of information and telecommunication technology has created more favorable conditions for many companies to globalize operations. The main goal of these companies is to provide an uninterrupted flow of information across organizational settings, regardless of geographical distance or the local environment. Information systems in the area of e-commerce can support achievement of this goal, only if they are viewed in a comprehensive, global way. Business globalization and strong competition require a new digital enterprise concept, as evidenced by the increasing investment in specialized and client-oriented technologies based on web and the Internet. The main goal of this paper is to analyze the primary elements of the information technology (IT) infrastructure of global e-businesses, their operational models and method of implementation. The end result of this analysis is to identify problems in the implementation of global e-commerce and propose possible solutions. In this context, an example of an agricultural company "1 December" in Serbia which successfully solved these problems, was analyzed. The general claim that e-commerce increases the competitiveness and profitability of this company was confirmed by the business practices of this organization.

The first chapter deals with global companies and the impact of the globalization process on e-commerce. In this context, these companies adopt a strategic approach to the implementation of global e-commerce, then formulate the most suitable strategy for functioning in a highly integrated and electronically networked global economic system. The second chapter deals with global e-commerce models that are available to companies that plan to market in global markets via the Internet. Special attention is paid to the B2C (Business-to-Consumer) model of global e-business and mobile e-commerce. In order to successfully implement this model, a global company should adopt a technological and business concept of global customer relationship management. The third chapter discusses the information technology (IT) framework for the implementation of global e-business. Every company that plans global e-commerce needs to ensure the smooth functioning of the basic elements of IT infrastructure, such as hardware infrastructure, global business applications, global telecommunication networks and databases. Also, it points to the basic problems and failures in designing global websites that are being developed to facilitate and more effectively position global companies into the global electronic marketplace. The fourth chapter analyzes the implementation of global e-commerce, explaining the most important activities of the implementation process. The first group of activities, which primarily emphasize the business and market dimension, include: analysis of business requirements, identification of target markets, development of market profiles, decomposition of business requirements, which can be functional (internationalization, localization) and requirements related to data (data concepts, data standards, etc.). The second group of activities relates to the technical 
implementation of global e-commerce and the construction of a website. These activities include the development, testing, documentation and construction of a website. The fifth chapter deals with "1 December" company's e-commerce strategy. The practical example explains how this company has grown from a modest family business to a global company that penetrated the world market by successfully managing to take advantage of all modern e-commerce tools and quickly and efficiently applied them to their business operations. In the last, sixth chapter, an e-business plan for the Serbian market was presented. The abstract example of the farm was considered, or, in reality, this company would globalize its e-business in the territory of Serbia and neighboring countries, by adapting its strategy to domestic customers and consumers on the one hand, and business opportunities and conditions on the other.

\section{Materials and methods}

Corporate finance management can be viewed:

1) As a scientific discipline - studying the management of finance in an enterprise, is closely related to accounting and economics. It evolved from the science of finance over the last century, especially in the 1920's. At that time, with the development of joint stock companies and the expansion of financial markets, a large number of scientific papers appeared in this field.

2) As a function of the company - includes the activities of enterprises related to the acquisition, financing and management of assets, the main task of which is the provision of permanent sources of financing. Financial management is done through the management of cash flows; the financial activity is managed on the basis of knowledge of the economy, financial rights, etc.; Financial management includes planning, organization, motivation, control, and the like.

Financial management has a special place in the financial system because business finances are closely related to management, technology, resources, personnel, etc. Errors in financial management can lead to negative consequences in these areas, and financial problems are often the source of deeper business problems.

In Serbia, as well as in other transitional countries, financial management is only beginning to gain real significance, while in the first-world, market-driven countries it has long severed as a significant scientific discipline and practical activity.

\section{Financial management of the company}

The management of finance by traditional principle was the problem of acquiring capital, that is, in relation to liabilities of the balance sheet, which did not give an answer to the question whether the enterprise invests capital in a secure alternative. Previously, the financial function reacted to decisions that are brought by others. This approach was not sufficiently comprehensive. In the late 1950s, due to rapid economic growth and rapid technological changes, financial institutions, such as pension funds 
and insurance organizations, experienced a major upswing. That is why the scope of manager's responsibilities increased: based on needs of shareholders and creditors (deposits), employees (wages), the state (taxes), and suppliers (collection). Managers are interested in the success of the company, because it provides them with higher salaries, and also because they are often shareholders. There was a need to use scientific methods in making financial decisions, and a modern approach to finance was developed. Unlike the traditional approach, modern access to finance is based on rapid economic growth and technological change, which has led to a significant increase in the importance of responsibility for the success of the company. Apart from the problem of purchasing capital, it deals with the assets and liabilities of the balance sheet.

Financial management should provide answers to three important issues:

- What type of assets should the company obtain?

- What is the total amount of assets the company should have?

- How should the funds needed be financed?

\section{The importance of finances in the process of reproduction}

Finances represent the totality of the relations created in the process of creating monetary funds of economic entities and the state, and their use in order to reproduce, encourage and meet social needs. The reproduction process consists of four stages: production, exchange, distribution and consumption. Financial resources are created at the stage of production, when a new value arises, but in reality, the financial resource is created only at the point of exchange, once newly created value is realized. Finances are divided into three areas: finance of business entities, insurance and state finances. Within each, special groups can be singled out. Each area is specific, but they form together a financial system of a country. Their connection is realized through banking system institutions. According to sources of creation, financial resources are divided into:

a) Those that are formed on the basis of own funds, share capital, shareholding capital,

b) Those who are in the financial market as a result of securities operations

c) Re-distributed, budget subsidies, insurance fees.

It is possible to distinguish (though not completely precisely) the three basic cycles of business activity:

- Investment cycle - contains a return relationship between investment (investment in financial resources) and in-process (profit-taking) operations of companies;

- The current operations cycle - contains the backward linkage of supply, production and placement operations (in some companies it is difficult to separate investment from current operations);

- Cash cycle - operations related to the management of free cash assets of the company: covering the short - term financial needs of enterprises by using loans. 


\section{The financial system of companies and the influence of prices on finances}

Financial assets are required by the company for his:

1. Establishment - initial money is needed, which will provide the necessary factors of production;

2. Business - it is necessary to finance current operations, working capital, solvency and profitability;

3. Development - In order to enable development, new investments need to be provided.

All business decisions of the company have financial implications (positive or negative). All stages of the business process (procurement, production, sales, financing) should be viewed from a financial point of view. All assets and sources of financing, revenues and expenditures and cash flows are monitored and monitored. Salaries, taxes, dividends and other obligations are paid in cash. There factors for the financial system of a company. Price is an economic instrument whereby the value of a product gets a novel expression and becomes a distribution object. This is one of the main factors that influence the further distribution process: the price depends on the amount of cash available to the company to dispose of; Within the price, the proportions of the future distribution are determined.

The price through supply and demand influences the volume of financial sources and financial flows: the higher the price, the lower the demand (except for the most necessary goods and for goods of special demand). The price affects the period of capital revaluation and credit risk: by setting a certain level of the price, it can accelerate or slow down the turnover of capital; When moving goods (or finite instruments) from a producer (eminent) to a consumer (investor), the risk of spoilage or loss can be downloaded or handled.

\section{The main financial goal of the company}

The main objective of financial management at the state level is to consolidate the system of social relations - so that the various layers of society are not in an illegal state. Therefore, when making financial decisions, it is necessary: to evaluate their consequences, to try to reduce the costs of their realization, etc. The main financial goal of a food company is to maximize profits. For shareholders, the main goal is to maximize their assets. This is achieved by increasing the market value of the shares. There are three main decisions on which it depends whether the value of the actions and, therefore, the food company will increase or decrease:

1. The decision on investment (investment) in material / financial assets affects the structure of assets in the asset. If the investments are safe and profitable, they will lead to an increase in the market value of the shares.

2. The financing decision defines the structure of the financing of the company, i.e. means of obtaining funds for covering all obligations: from own or other, long-term or short-term sources. 
3. Dividends and retained earnings decisions - if more dividends are higher, the demand for shares is also higher; retained earnings increase the firm's permanent capital, which can be used for investing.

These three decisions are interdependent. It is necessary to strive for their optimal combination in relation to the main goal - profit maximization, without compromising the survival of the company. Often, as a way of maximizing profits, maximization of earnings per share is advocated, which is not an appropriate goal.

\section{Secondary financial goals of the company}

The secondary objectives are: maximizing the net profit in the long run and strengthening the financial viability of the organization. Net profit is part of the gross profit (minus interest and taxes) that remains available to the company. The net profit is divided into joint stock companies:

- Dividend profit - from which dividends are paid,

- Retained earnings - Increases fixed capital, used to finance development, cover losses

- Reserves - for the coverage of business and financial risk.

Maximizing the overall win is not the best solution, because if this gain, for example, investors and shareholders will not benefit from it. The goal is to maximize the net profit achieved by maximizing revenue, and minimizing costs and minimizing taxes. The financial strength is a quantitative and qualitative component:

Quantitative financial strength - scope and value of assets. It requires: the matching of fixed assets with a business task (in order to avoid any unused capacity), the alignment of basic and working capital (in order to avoid stagnation); harmonization of short-term and long-term financing, harmonization of own and other capital, preservation of the financial balance. The quality of the financial strength is a permanent ability: payment of obligations within the term (solvency), short-term and long-term financing (current business and development), investments in material and financial assets, satisfying the financial needs of employees, managers and the state; preserving and increasing the property of the owner. The quality of financial strength is primary because it determines the possibility of doing business, while quantity determines the scope of business.

\section{Tasks and objectives of financial management}

In small-and medium-sized enterprises, financial activity is carried out by other departments: bookkeeping and information services. In big food companies, financial activities are clearly distributed between financial, IT and control services.

Organize characters to create an organizational structure. The choice of the organizational structure is from a large number of factors, such as the size of food organizations, activity, market, technology used, time to obtain products, time for decision making, information system, the type of management in the food company, the organizational 
culture and organizational-legal form of the above-mentioned company.

These factors also affect the content of financial management activities differently. Activity management of finances can be structured in the following way:

1) General financial analysis and planning;

2) Providing companies with financial resources (management of sources of funds); and,

3) Allocation of financial resources (investment policy and asset management).

\section{Classification of financial management decisions}

Starting from efficiency, variants of decisions and systems can be:

- Ordinary - efficiency meets the norms for this industry. There are three types of variants: an inefficient variant (does not allow the problem to be resolved), rational (optimal) and optimal.

- Synergy - when they are accepted, efficiency is rising rapidly. Synergy solutions occur for example when developing new technologies. In financial management, the synergy effect of decision making is called the leverage effect.

- Asynergic - Reducing efficiency (e.g. due to delays in decision making).

If the food company wants to increase the volume of production, to restore the material base, etc, it has to invest. Influencing the investment decision influences the value of the project, the type of investment, the risk profile, the impact on profitability, among other factors.

There factors form the basis of investment allocations:

1. Spatial - if there are a few unknowns. projects for which there are no resources, inv. portfolio;

2. Time - if there are several independent, accessible projects that food company can not realize at the same time in the same year, optimal projects should be allocated over the years.

The decisions of financial management must include the following operations:

1) problem detection;

2) collecting information;

3) analysis of information;

4) setting the goal to be achieved by solving the problem;

5) decomposition of this goal into the objectives of each of the entities in financial relations;

6) determining the criteria for assessing the efficiency of each subject; 
7) analysis of the possible consequences of making a decision;

8) development and assessment of different alternatives;

9) making decisions, reporting to perpetrators, execution and control of execution.

The interests of shareholders - to increase their assets, workers - are better earnings and better working conditions, and the interests of the state are - charging higher taxes - are often oppositie and contradictory to one another. If the objectives of managers and shareholders differ, management can act its own interest instead of the interests of shareholders. Managers will make optimal decisions only if they are motivated and controlled by stockholders.

\section{Financial management of working capital}

Total funds for financing business: equity of the owner, debt to third parties and earnings from business, are used for the acquisition of basic and working capital. Fixed assets are funds that are gradually spent and used longer in the business: land, construction objects, debt claims. Current assets are constantly spent in the production process or purchased for sale. These funds are often converted into one form to another (money / natural) and run in shorter terms. These are: all forms of money, short-term securities, short-term receivables (whose maturity is one year), all assets that turn around in the course of the year, all stocks.

The management of working capital assumes that investments in total working capital is maximized to realize as much business volume as possible. This maximizes profitability and maintains an adequate level of solvency.

The company should determine the optimal volume of net working capital - the difference between total working capital and short-term liabilities (obligations to suppliers for purchasing raw materials and materials, current operating expenses, and short-term bank loans). This volume is an indicator (not a cause) of solvency, it determines the profitability and risk, and arises from different combinations of longterm and short-term sources of financing.

\section{Inventory management}

An organization's inventory comprises a large part of total business assets, and require large cash investments. It is therefore important to maintain an optimal level of inventory - the level that represents the lowest total inventory costs. The inventory management costs are:

1. Costs of stock acquisition - arise when replacing spent raw materials and materials for production, as well as when replacing the stock of finished products for sale purposes. These are costs of: ordering, receiving, unloading, controlling and stockpiling ... 
2. The costs of keeping inventories - are due to the existence and holding of inventories in the enterprise. These are the costs of storing, tying up capital, property tax, and so on.

3. Costs of inventory shortage - arise when there is a lack of stock of raw materials and materials necessary for production, as well as a lack of stock of finished products necessary to satisfy customer orders. These costs include: missed sales revenue, losses due to non-performance of production plans, loss of reputation among customers.

There are two basic types of stock decisions:

a) how much supplies should be obtained in one order - the optimal size of the order is the one that causes the lowest total cost of obtaining and holding the inventory;

b) at what intervals to obtain supplies - the optimal frequency of obtaining stock is the one that causes the lowest holding costs and lack of supplies.

\section{Managing money}

Managing money involves a constant balancing act between solvency and profitability, which is achieved by establishing an optimal cash balance. Each periodic cash deficit (reducing solvency, increased profitability) must have sources of coverage, while any surplus (reducing profitability because it does not generate returns, solvency increase) should have the possibility of a viable outlay outside regular business. When determining the minimum cash balance required, it is necessary to observe the costs that arise in relation to cash (holding, shortage, and cash transactions). The optimal cash balance is the balance that minimizes the total cost of cash, such as: the cost of holding cash - so there is no yield, cash drawdown - so it is not used by favorable purchase conditions, the costs of cash transactions - administrative, manipulative, commissions. In order to determine the optimal cash balance, the financial method is most often used, which is based on the fact that the minimum cash balance should be equal to the average annual balance required for the regular activities of the company. The cash turnover coefficient shows how many cash cycles occur during one calendar year. The cash cycle is the number of days that elapse from the moment of issue until the moment of cash receipt. The cash turnover coefficient is obtained when the number of days per year is divided by the (average) duration of a single craft. The task of the finance management is to reduce the average duration of the craft, i.e. to increase the cash turnover ratio. The goal of the company is to reduce the balance and total cash costs. Cash management should aim to get as much cash as possible and to invest, without compromising solvency. Temporarily free cash should be invested in securities, in order to generate yield. The company may acquire cash by issuing and selling securities. Non-cash payments from the payees' current account arrive at the current account of the company. The task of financial management is to synchronize the flows and outflows as much as possible (due to surpluses and deficits). Cash is paid only when cashless payment can not be made (retail sales, services to the population). Cash is kept in the cash register. Cash in arrears must be paid to the current account, and cash for payments is withdrawn from the current account. The inflow of money takes into account: money that is collected from sales, 
borrowing (borrowing), if owners increase capital or reduce working capital. The inflow serves primarily to pay for procurement, to ensure business continuity. The outflow of money implies: investment in fixed assets, debt repayment, dividend payment and the increase in working capital. The difference between inflow and outflow increases or decreases the balance of money. Solvency is maintained through the adjustment of inflow and outflow. The inflow of money can be stimulated and accelerated, and the outflow slowed down. However, both have their own cost: the cost of convenience for early payment, that is, accepting higher interest rates, securing payments, etc.

\section{Financial forecasting and programming}

Deciding and forecasting are inextricably linked. The time period from the time the information is received to the moment of execution of the decision is called the administrative decision cycle $(\mathrm{Cu}) . \mathrm{Cu}=\mathrm{Vi}+\mathrm{Vd}+\mathrm{Vs}$, where: You have a time interval from the moment you receive the information to the moment of making the decision; $\mathrm{Vd}$ interval for decision making; and Vs for communicating and executing the decision made.

In the process of developing administrative decisions, it is necessary to make a forecast of its feasibility, which depends on the financial resources, the existence of the necessary organizational structures, and the motivation of the executors.

Financial forecasting is the examination of a possible situation, the possible ways to achieve this state of finances in the future, and assessing the probability of its realization. The main objectives of financial programming are: to specify the way to achieve goals; specifying the sources, flows and deadlines for the arrival of financial resources; specifying resource consumption; increasing the efficiency of resource consumption and ensuring control over the execution of the program.

\section{The concept of financial planning}

Financial planning is the presentation of various plans - procurement, production, sales - by set out financial indicators. Funding planning is synthesized in the financial plan. In financial plans, the goal of financial policy - the financial strength - is placed in time and space in a worthwhile manner. The financial plans show: what is going to be done, how, who will achieve the goal, when and where. The financial plan defines: sources of financing, allocation of financial resources, mandatory payments, deadlines for realization of financial measures. In this regard, financial planning can be divided into two stages:

a) Planning financial resources and flows; and,

b) Own financial planning.

According to the planning period, there are several timeframes: long-term (a period of 5 years or more), medium-term (up to 5 years) and short-term planning (up to one year). 
Financial planning includes:

1) The plan of the profit and loss account;

2) Balance sheet plan;

3) Cash flow plan; and,

4) Plan of long-term investments (it expresses the scope, structure, duration of investment and structure of sources of financing).

\section{Financial Planning}

Upstream planning is the preparation of a plan for the enterprise as a whole. Financial planning is tasked with drafting and presenting the plan of activities of the enterprise and its needs for business assets in the sources of financing expressed in monetary form. The Summary Plan is not a simple set of organizational plans, it refers to the company as a whole - the plans of individual organizational units must be aligned and targeted towards the same goal. Monetary indicators of total business activity are represented by revenues, expenditures and financial results that are presented inclusively by periodic balance success. Since the revenue, expenditure and financial result of the various products and services, revenues, expenditures and financial results must be allocated to the bearers in the preparation of the supplementary financial plan. Planning revenue and expenditure is not sufficient in itself. The company must plan the total and additional needs for business assets without which the financial result can not be realized. The most important segment of the underlying financial plan is the sales plan - all other plans are conditional to this plan. The Initial Plan is a sales plan. It is based on long-term sales planning. Based on the sales plan, a production plan and production costs are adopted. The production plan is the basis for the preparation of the procurement plan and the procurement costs. All these plans are preliminary partial plans, but they are consolidated into the planned profit and loss account as a summary term. In addition to the profit and loss account, the company must also plan the balance sheet - it must plan the needs for business assets without which the planned volume of activities and the financial result could not be achieved. This plan includes: investment plans in certain categories of business assets (fixed assets, inventories, receivables, and cash) and the source plans from which these investments should be financed. The cash flow plan, which takes a central place in the plan, is important. The annual financial plan includes the plan and costs of sales, the plan and costs of production, the plan and costs of procurement, the R\&D cost plan, the administration cost plan, the capital investment plan, the cash flow plan, the financing plan and the planned balance sheet and success - thereby representing a sophisticated financial plan. This is a comprehensive and coordinated plan of the activities of the company and its needs for business assets and sources of financing for a certain period of time Milojevic et al., (2017). 


\section{Results}

The plan of the profit and loss account shows the expected amount of the financial result and its structure for a specific period. This plan is broken down by months or by product types, sales territories, customers, etc. This plans a net profit, which defines: profitability, preservation and increase of assets and maintenance of solvency. Within the planning of the profit and loss account, risks are identified and the possibility of their reduction is examined.

The correction of the profit and loss account is carried out according to the following scheme:

Changes in Current Assets and Liabilities Cash Influence Way of Correction

Increase in working capital (except cash) Decrease cash Retract from net profit

Reduction of working capital (other than cash) Increases cash Add net profit

Increase in short-term liabilities Increases cash Add net profit

Reduction of short-term liabilities Reduces cash Retract from net profit

\section{Planning cash flows - cash}

In order to protect solvency and maximize profitability, a continuous cash flow is required. The company can not ideally match the monetary benefits and losses. Therefore, at any time, there must be a cash balance, i.e. money supply that ensures the continuity of financial activity.

Cash flow control instruments are:

- Cash flow statements - synthesise cash receipts and benefits and show changes in the cash balance;

- Cash flow plans - analyze future receipts and benefits that will affect the increase or decrease in the cash balance.

There are two types of cash planning methods:

1. Balance method - based on various information (financial position of the company, planned volume of business activity, etc.), the expected balance sheet, profit and loss account and cash balance are projected at the end of the plan period. Within the balance methods, the following are distinguished:

- the projected balance sheet method - comparing the initial and projected balance sheet at the end of the plan period;

- the method of the adjusted income statement - translation of the planned revenues, expenses and net profit from the profit and loss account to the expected income, issuance and net cash flow from operations. 
2. Dynamic methods - a dynamic cash plan is developed in three phases:

- A plan for receiving and giving cash on various bases is adopted, with the basic content consisting of flows related to regular business;

- a surplus and cash deficit plan - confronts receivables and benefits over a specific period of time and determines a surplus or deficit in relation to the minimum cash balance;

- Financing plan - determines the dynamics of borrowing and repayment, depending on whether it is a deficit or a surplus of cash.

\section{Discussions}

Traditional business is based on the use of structured paper documents in a previously defined and generally accepted communication between participants taking part in the business process. In today's modern business conditions, business transactions are primarily realized electronically. It is about e-business (e-commerce), which has been incorporated in almost every sphere of life. In general, e-commerce is the purchase and sale of information, products and services through a computer network and/or support for any type of business transaction Marjanović, (2008); Mičić et al., (2017).

E-commerce can also be interpreted as the use of computers in the implementation of business processes that arise by creating new opportunities, such as:

- A new, interactive way to access the market and partners, at the same time at the local and global level;

- The ability to perform certain business processes outside the company; and,

- Availability of plenty of information, with possible search elements and automated analysis; new models of business association, financial transactions and performance of business processes Stojanović, (2008).

The most popular e-commerce channel is the Internet. E-commerce emerged in the early 1980s, but only recently accelerated in adoption and development, primarily due to the Internet. There are two basic prerequisites for automating any business process. First, a description of all jobs in business processes that are automated must be defined. In other words, there must be a written document in electronic form, which contains a list of tasks for each individual workplace. The second is a description of the flow of information between jobs for each business process (»information workflow «), or a business process scenario (»event scenario«).

\section{Internet and globalization of business processes}

Globalization and the Internet symbolize the spirit of the times at the beginning of the new millennium and require looking at the world with a "fresh pair of eyes". The Internet as a "network of all networks" is a metaphor of the new digital age Milićević, (2002). In addition to being an internet network, it is also software, and a new interactive 
mass media, and ultimately implies a new way of thinking and a new culture. From an economic point of view, it is important that the Intenet provides the fastest possibility for growth in terms of sales and marketing in history, and the most effective means of communicating with the world at large. Changes experienced by enterprises of all sizes in the conditions of the Internet economy are compared with the changes that took place during the Industrial Revolution. While the Industrial Age shifted the transformation of physical resources, the information economy implies that the dominant resources include information and knowledge. It is believed that the success of the 21 st century economy will be based on the "3 I's" - information, ideas and intelligence. There is an evident increase in the demand for services, as well as the expansion of online e-commerce, which represents the affirmation of the new trading pattern. Thanks to the Internet, space and time barriers have been demolished, thereby reducing the importance of the physical location of the company. On the whole, the Internet has led to significant changes in the economy. Webonomy refers to the study of the production, distribution and consumption of goods, services and ideas over the web (World Wide Web) (Schwartz, 1997); Schiller, (2000); Serour and Henderson-Sellers, (2004).

Today we can talk about a new web generation that communicates, operates, buys and entertains via the Internet as a basic tool, which has created significant business opportunities for existing e-commerce companies, and formed the basis for the emergence of many new Internet companies. In this way, the Internet and digital media are opening up new ways to create wealth. Many companies use the Internet to communicate with their customers and suppliers, creating new digital e-commerce networks that bypass classic distribution channels Jovanovic and Milovanović, (2010).

They also use the Internet to accelerate and increase the efficiency of internal business processes. The Internet reduces communication costs when coordinating business activities and communicating with employees. Researchers and administrators have noted that the Internet is a fast, inexpensive way to collect and disseminate knowledge. Global connectivity and low cost of the Internet help companies reduce transactional and agency costs, allowing them to connect directly with suppliers, buyers and business partners, and coordinate global-level activities with limited resources. Web provides interactive multimedia capabilities that can be used to create new products and services and closer customer relationships Shaw (2002) and Sharma and Kitchens (2003). Communication can be tailored to the specific needs of individual users and market segments. In this context, it is important to pay attention to the "new rules" that are relevant to business success in new conditions:

- Companies focus on maximizing the value of the business network;

- Competitive advantage is achieved by companies that know how to unify decentralized control points in the network;

- Human attention remains a real and rare resource, which is primarily related to visiting the company's website and to communicating via e-mail and i-forums; 
- Physical proximity in the online world is replaced by multiple interactions at any time and from any point in the space - the transition from a concrete place to a global space;

- The principle of abundance rather than the rarity principle is affirmed in relation to the technological capabilities of multiplying electronic products at very low marginal costs;

- The achievement of the laws of growing yields is related to the characteristics of the network, whereby it is better to be connected to a larger network Shapiro and Varian, (1998); Ciric et al., (2018).

The process of globalization at the beginning of the new millennium is complex, multidimensional, full of controversy, dilemma and open issues. From the standpoint of the company, a strategic approach to globalization of business is relevant. It talks about a highly integrated and electronically networked global economic system.

However, the degree of globalization by individual activities is different. In addition, there are "winners" and "losers" of the globalization process. The rationalization strategy is a global strategy that implies directing activities to those parts of the global company, regardless of their location, which are most suitable for achieving desired results, and then sell products in those markets in the world where the highest profit is expected. In this way, managers need to consider factors such as costs, employee expertise, raw materials and capacity availability, and make decisions about where specific jobs will be performed, striving for the best use of company resources around the world. In practice, a global strategy often involves decision makers' ideas where to locate and how to coordinate individual activities. Most global strategies include a combination of foreign trade activities and foreign direct investment that reflect the dispersion of business activities. Trade and direct investment can be complementary, with very complex internal and external transactions and relationships. In recent times, there are often global e-commerce strategies, where global access is achieved thanks to the ability to communicate over the Internet. IT Hoffman and Novak, (2000); Humphrey et. al., (2003); Collison, (2006).

\section{Development of global information and technology capabilities}

Do global and multinational companies that advocate for their own global strategic vision truly accept such a vision? Then, after the implementation of their own global strategic vision, are they working to develop global information and technology (IT) opportunities to support such a vision?

If this is the case, then what is the most important mechanism that enables the development of global IT capabilities?

The illustration model shown in the picture (Figure 1) is a model for the development of global IT capabilities. 
Figure 1. The image model illustrated in the figure is a model of global IT capabilities

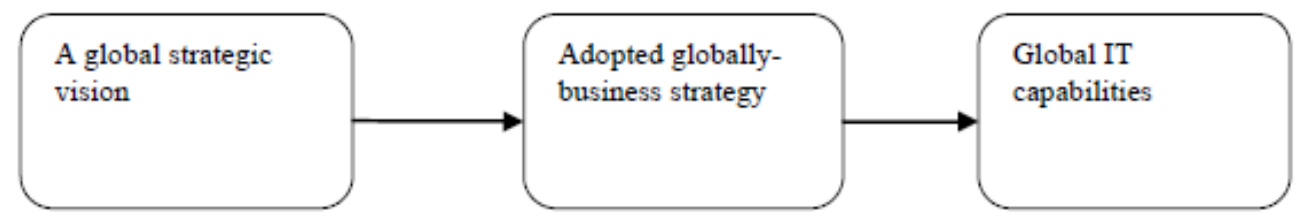

Source: Mičić, 2018

Note: Own creation of the author according to the research model

Burn and Ash (2001) and Bean (2003) state that these three main issues are listed in case studies conducted between 130 global companies. The answer to these three questions is the key to thinking about how the company develops through the process of globalization and what role the IT sector has in the role.

\section{Conclusions}

Based on the study, we conclude that there are three basic global IT challenges, each characteristic of a particular type of global company:

1. Low level of geographical dispersion of business and high level of centralization is the approach that is mostly applied in small companies operating in a few countries. In this case, parent companies must have information systems (ISs) that allow much better planning for international information systems. For example, a Japanese domestic manufacturer runs a job in several countries and supplies its production bases using common data and application components through its own IT system.

2. High level of geographical dispersion of business and low level of centralization is most suited to large conglomerates that enable their own branches to develop their own strategic IT software. For example, one of the 100 largest world-renowned banks, the Bank of Australia and New Zealand, provides support through several affiliates and subsidiaries in several Asian countries in addition to its headquarters in Australia and New Zealand. Companies allow their local affiliates a significant level of self-control in the development of their own IT systems and strategies.

3. A high level of geographical dispersion of business and a high level of centralization is a structure chosen by global companies that have established strong strategic alliances with companies in the host countries. This approach includes both domestic and international ISs and encourages communication through IT within the company. For example, when a Pittsburgh manufacturer of glass, lacquer and chemicals made acquisitions and association with overseas countries, the company invested a lot of time in designing an appropriate information system to fit the corporate culture and local conditions. Their IT system in England is different from those in South America and Asia, due to different cultures of the local population and various personal opportunities. Today's integrated systems enable quick access to information in any part of the world. All three strategies are correct. What's important is to choose the right 
one based on the profile of the company. It is essential that IT managers determine the type of organization that belongs to their company.

\section{Acknowledgements}

We want to thank the farms for the efforts they have taken to collect data from the pig farm "December 1", based in Zitoradji, which deserves special thanks for providing necessary support throughout the duration of this study.

\section{Conflict of interests}

The authors declare no conflict of interest.

\section{References}

1. Bean, J. (2003). Engineering Global E-Commerce Sites. San Francisco: Morgan Kaufmann Publishers.

2. Burn, M. J., \& Ash, G. C. (2001). Managing Changefore - Business Success. Slovenia, Bled: 14th Bled Electronic Commerce Conference, 25-26.

3. Collison, S. (2006). Beginnig CSS Web Development: From Novice ti Professional. New York: Springer-Verlag.

4. Ciric, M., Ciric, M., Kuzman, B., \& Zekavica, A. (2018). Farmer innovativeness and its impact on internet and social media adoption Economics of Agriculture 1/2018 Vol. 65, No. 1, Scientific Society of Agricultural Economists of the Balkans, Belgrade, pp. 243-256.

5. Hoffman, D. L., \& Novak, T. P. (2000). How to Acquire Customers on the Web. Harvard Business Review, No 3, pp. 179-188.

6. Humphrey, J., Mansell, R., Paré, D., \& Schmitz, H. (2003). The Reality of E-commerce with Developing Countries. United Kingdom: Institute of Development Studies at the University of Sussex.

7. International Organization for Standardization (ISO). Available in: http:// www.iso.org/iso/home.html (May 14, 2018)

8. International Telecommunications Union (ITU). Available in: http://www.itu. int/en/Pages/default.aspx (May 14, 2018)

9. Jovanovic, R., \& Milovanovic, S. (2010). E-Commerce, Niš, Faculty of Economics in Niš, [in Serbian: Јовановић, Р., \& Миловановић, С. (2010). Електронско пословање, Ниш: Економски факултет].

10. Marjanovic, A. (2008). E-business - seminar work. Belgrade: Faculty of Organizational Sciences, [in Serbian: Марјановић, А. (2008). Електронско пословање - семинарски рад. Београд: Факултет организационих наука]. 
11. Micic, I., Rajic, Z., \& Micic, I., I. (2017). Strategic Risk and Payments in Electronic Banking, Scientific Society of Agricultural Economists of the Balkans, Belgrade, [in Serbian: Мичић, И., Рајић, 3., \& Мичић И. И. (2017). Стратешки ризик и плаћања у електронском банкарству].

12. Milicevic, V. (2002). Internet economy. Belgrade: Faculty of Organizational Sciences, [in Serbian: Милићевић, В. (2002). Интернет економија. Београд: ФОН].

13. Milojević, I., Ignjatijević, S., \& Micic, I. (2017). The application of Markov's Stochastic processes in risk assessment for accounting infromation systems, UDC 657.4, Economics of Agriculture, Vol. 64, No. 2, Scientific Society of Agricultural Economists of the Balkans, Belgrade, pp. 551-560.

14. SAP Business Management Software Solutions, Applications and Services. Available in: http://www.sap.com/index.epx (March 29, 2018)

15. Schiller, D. (2000). Digital Capitalism-Networking the Global Market System. England, London: The MIT Press.

16. Schwartz, E. (1997). Webonomics - Nine Essential Principles for Growing Your Business on the World

Wide Web. England: Penguin Books.

17. Serour, M. K., \& Henderson-Sellers, B. (2004). Organizational Aspects of Transformation to E-Business: A Case Study. Sydney: University of Technology, IADIS International Conference e-Society.

18. Shapiro, C., \& Varian, R. (1998). Information Rules, A Strategic Guide to the Network Economy. Boston Harvard Business School Press.

19. Sharma K. S., \& Kitchens F. (2003). Assessing Technology Integration for E-business. South Australia, Adelaide: 7th Pacific Asia Conference on Information Systems, 10-13.

20. Shaw M. (2002). E-Business Management: Integration of Web Technologies with Business Models. Series: Integrated Series in Information Systems, Vol.1.

21. Stojanovic, M. (2008). Elektronic Business in culture - thesis. Belgrade: Faculty of Organizational Sciences, [in Serbian: Стојановић, М. (2008). Електорнско пословање у култури - дипломски рад. Београд: Факултет организационих наука]. 